\title{
Персонажи Книги книг в сравнениях белорусов и украинцев (на фоне других языков)*
}

\begin{abstract}
И. В. КУЗНЕЦОВА
Кафедра педагогики и методики начального образования, Чувашский государственный педагогический университет им. И. Я. Яковлева, ул. К. Маркса, д. 38, RU-428000 Чебоксары E-mail: irinak47@yandex.ru
\end{abstract}

(Received: 24 August 2016; accepted: 18 October 2016)

\begin{abstract}
The paper studies the presentation of Belarusian and Ukrainian biblical similes in dictionaries as well as their use by native speakers. Some of the examples are supplied with etymological commentaries.

Keywords: biblical phraseology, phraseography, Belarusian, Ukrainian, similes, biblical characters
\end{abstract}

Среди белорусских и украинских фразеобиблеизмов немало устойчивых сравнений: бел. голас як іерыхонская (ерыхонская) труба 'трубный, громкий, мощный и низкий голос'; крычащь (грымечь) як іерыхонская (ерыхонская) труба 'мощно, низко звучать' (ЛЕПЕшАў 2: 18, 453); укр. вертатися немов (як) пес до своєї блювотини 'упрямо возобновлять какое-либо прерванное занятие', ; бел. ждащь як з неба пасланща 'ждать добрых вестей' (FEDEROWSKI 1935: 364); чакаць як бога (ЛЕпешАў 1: 108); ждже як бога (Фядосік 1979: 319); жде як бога 'ждать с нетерпением' (Юрченко-Івченко 1993: 16); ; укр. жде як пана бога 'ждать с нетерпением с надеждой на помощь' (ЮрченкоІвченко 1993: 109) и др. Рассмотрим компаративизмы с компонентом-персонажем Библии. Многие из них известны разным языкам. Так, потомок Еноха Мафусаил прославился своим долголетием: он жил 969 лет (Бт 5: 21-27), откуда укр. старий як Мафусаӥл (НУФС 1: 27).

* Работа выполнена при финансовой поддержке Российского научного гуманитарного фонда. Проект «Ключевые концепты русских народных сравнений (опыт идеографического словаря)» (№ 14-04-00090/14; шифр ИАС 31.16.571.2014).

${ }^{1}$ Компаративизм восходит к библейской истории города Иерихон. Хотя стены крепости разрушились не от звука труб, а от единого громкого крика сынов Израилевых, в бытовом сознании причина их разрушения - мощный звук трубы: рус. голос как труба иерихонская (иерихонская труба); звучать как труба иерихонская (ОГОльцеВ 1994: 415); болг. глас като йерихонска тръба; ехтя (еча) като йерихонска тръба (КювлиЕВА-МишАйковА 1986: 118; 131); польск. potężny jak trąba jerychoński (SKORUPKA 1: 310).

${ }_{2}^{2}$ Рус. возвращаться как (аки) пес на свою блевотину (своя блевотины) (Попов 1976: 181; МЛТ 2010: 357); болг. връщам се като куче на бълвоча си (КювлиЕВА-МишАйковА 1986: 114); серб. поврће се ка' и пас на бљувотину (БНМ 1968: 275). Выражение из Ветхого Завета: Как пес возвращается на блевотину свою - так глупый повторяет глупость свою (Притч 26: 11).

${ }^{3}$ Рус. ждать как Бога (СОСВ 1997: 32); макед. очекува (чека) како Бога (FINK 2006: 238). 
Ветхозаветный праведник стал символом крайней бедности у многих народов: бел. бедны як Іоў (МАСлОВА 2001: 168); укр. бідний як Іов (НУФС 1: 341), а Лазарь Убогий - персонаж евангельской притчи о богаче и нищем не только бедности, ${ }^{4}$ но и крайне болезненного состояния: бел. выглядаць як чысты Лазар 'о болезненном, изможденном человеке'; ляжаць як Лазар 'о лежачем больном, инвалиде' (FEDEROWSKI 1935: 170); як Лазор мучыция 'о тяжелобольном, обычно лежачем калеке' (СБГ 3: 90). Заметим, что прилагательное убогий в рус. убог как Лазарь (ДАЛь 1993: 176) совмещает в себе два значения: ‘бедный, неимущий, нищий' и 'увечный, калека, неисцелимо больной, имеющий какой-л. физический недостаток’ (ДАль 4: 912-913, МАС 4: 445). Его имя мы видим также в рус. болен как Лазарь 'о тяжелобольном, измученном болезнями человеке' (БМС 2005: 373); наряжаться/нарядиться Лазарем 'о бедно, грязно, по-нищенски одетом человеке' (ССРЯ 2003: 212); польск. jak Łazarz (łazarz) 'изможденный, болезненного вида, живые мощи', leżeć jak Łazarz 'лежать в одиночестве, всеми покинутым' (ПРФС 1: 622); wyglada jak Łazarz 'о бедно, грязно, по-нищенски одетом и изможденно выглядящем человеке’ (NKPP 3: 338); кашуб. leżec jak taki łazôrz [= нищий] 'о ком-либо грязном, лежащем в лохмотьях или в грязи' (TREDER 1989: 137); в.-луж. žałostny kaž chudy Lazarus 'о человеке, вызывающем своим видом жалость’ (САВКА 2002: 139).

Имя библейского мудреца мотивировало бел. разумный нібы Саламон (Federowski 1935: 170); укр. мудрий як Соломон (Саламон, Салимон); як мудрий Салимон; премудрий як Саламон (ФРАНКО 2: 415, 588; ЮРЧЕНКО-ІВЧЕНКО 1993: 130); розсудив як изар Соломон (Тимошик 2007: 107); лемк. мудрый як Соломон (Шаламун, Саламун краль) (ВАРхол-Івченко 1990: 126, 118, 145). ${ }^{5}$ Притяжательное прилагательное от имени израильского царя часто употребляется с целью создания иронии при характеристике неумного человека: бел. разумны як Саламонавы порткі 'глупый, недалекий человек' (FEDEROWSKI 1935: 271); такі мудрэи як Саламонавы гаці 'о сомнительном «мудреце»'; хітрыз ${ }^{6}$ як Саламонавыя порткі 'считать себя хитрым, мудрым’ (СБГ 1:437); укр. мудрий як итани Соломона (Соломонові штани) (ФРАнко 3: 492, ДоБРОЛЬОжА 2003: 14); розумний як Соломонові портки (ДоБРОЛьОжА 2003: 15); розумний як Соломонів патинок (папуцьь) (НомИС 1993: 293, ЮрченКО-ІвчеНко 1993: 109); лемк. мудрый як Соломоновы тачі (ногавиці) (ВАРХОЛ-ІВчеНКО 1990: 92). ${ }^{7}$

${ }^{4}$ Рус. беден как Лазарь (МихеЛьСОН 1: 86); болг. сиромах като бедния Лазар (НБФР 1: 107); англ. as poor as Lazarus (БЕТЕХТИНА 1999: 86); нем. arm wie Lazarus [sein] (WALTER 2008: 187) и др.

${ }^{5}$ Об эквивалентах устойчивых сравнений с именами Мафусаил, Иов, Лазарь, Соломон в других языках см. КУзНЕцОВА 2016: 53-56.

${ }^{6}$ Хитрый в славянских языках этимологически - 'знающий, сообразительный, сметливый’: ср. польск. chytry jak salomonowe portki; чеш. chytrý jako šalomouni̊v knoflik u gatí.

${ }^{7}$ Подробнее об эквивалентах и аналогах этих фразеологизмов, а также о других компаративизмах с именем этого героя в разных языках см. КузнЕцовА 2014: 346-347. 
Имена прародителей человечества ${ }^{8}$ встречаются в бел. жыџь як Адам у раю (раі) 'жить беззаботно, хорошо' (Довровольский 1894: 5); пращаващь як Адам $i$ Ева 'много, тяжело трудиться', укр. як Адам $i$ Сва 'о совсем раздетых людях’ (Юрченко-Івченко 1993: 9). По ветхозаветному преданию (Бт 4: 1-17), у Адама и Евы было два сына: старший, Каин, был земледельцем, а младший, Авель, пас овец. Однажды Каин принес в дар богу Яхве плоды земли, а Авель - первородных ягнят от стада своего. «И призрел Бог на Авеля и на дар его, а на Каина и на дар его не призрел. Каин сильно огорчился, и поникло лицо его... И когда они были в поле, восстал Каин на Авеля, брата своего, и убил его» (Бт 4: 4-8). В библейском тексте ничего не говорится ни о способе убийства Каином Авеля, ни об орудии убийства. В апокрифической литературе приводятся различные версии братоубийства: Каин задушил Авеля, убил камнем, камышом, палкой, каменным оружием, ослиной челюстью, веткой древа познания и пр. (ПАПАзян 1987: 609). В живописи орудие убийства - камень, топор, мотыга, лопата или серп (BRAUNFELS 1990: 7). Свою версию содержат и близкие по образности народные восточнославянские обороты: укр. підняв на вилах як Каїн Авеля 'очень жестоко, подло убил' (Юрченко-Івченко 1993: 22); кубан. пырять вилами как Каин Авеля 'о колющем, накалывающем или протыкающем что-л. силой или злостью человеке' (БСРНС 2008: 239). Здесь прослеживается ассоциативная связь с местом первого убийства на земле - полем: «И сказал Каин Авелю, брату своему: [пойдем в поле]. И когда они были в поле, восстал Каин на Авеля, брата своего, и убил его» (Бт 4: 8) и с интерпретацией библейского текста в фольклоре (ср. зафиксированное И. М. Сиротом выражение Авеля Каин на поле манил). Однако данные фразеологизмы восходят не к строкам Библии, а к этиологическим легендам славян о происхождении лунных пятен. Согласно некоторым из них, «старший Каин убил вилами младшего Авеля, и Бог поместил изображение братьев на лунный диск в наказание Каина и в назидание людям (о.-слав.). Ненависть Каина к Авелю возрастает и убывает вместе с луной, на полнолуние приходится братоубийство, и тогда на луне виден Каин, поднявший на вилы Авеля (укр.)» (БеловА 1999: 436). Сюжет об убийстве на Луне Каином Авеля известен также по русским и польским легендам (ВАРюхинА 2002: 31). Вероятно, легенда и сравнения возникли на основе общего фонового значения, присущим данным онома.

Имена библейских братьев стали символами: Авель - невинности, кротости, праведности, Каин - предателя, преступника, убийцы, вероломного человека. Краткая легенда о Каине и Авеле возникла «в очень отдаленную эпоху, когда древние евреи еще не вели кочевой образ жизни», и «поэтому Авель, пастырь овец, стал в их сказании любимцем Яхве и невинной жертвой

${ }^{8}$ О сравнениях с этими персонажами см. КузнЕцОВА 2012.

${ }^{9}$ Встречается в текстах: «Бо яны праиуюиь, як Адам і Ева... Аруць зямлю і прадуць лён» (Ў. Караткевіч: Каласы пад сярпом тваім, 1965). Ср. также с укр. «Як праотещь Адам, ходжу я тут за плугом. В поту лиця свій хліб насущний їм» (П. Куліш: «Вітаю глуш твою, куточку мій затишний...»-http://ukrbooks.com/ua/Vitaju_glush_tvoju_kutochku_mij_zatyshnyj/). 
земледельца Каина» (Косидовский 1990: 24). ${ }^{10}$ Многие исследователи Библии считают, что в ней отразился конфликт между скотоводами-кочевниками и народами, ведущими оседлый образ жизни и занятыми земледелием.

Укр. трусищця (труситься) як Каӥн 'дрожать мелкой дрожью (от страха)' ${ }^{11}$ (Номис 1993: 173, Гурин 1974: 212, Юрченко-Івченко 1993: 63); мов Каїн затрусивсь увесь 'задрожал' (СУМ 2: 110) отражают на библейском примере народные представления о грехе. Каин-братоубийца дрожит не потому, что он трус, а потому, что осознает совершенный грех. Это его наказание, кара за преступление; ср. подобные народные этиологические легенды об осине, листья которой постоянно дрожат, потому что она грешна. Распространены мотивировки дрожания листьев осины, связанные с историей Христа: она - единственное дерево, не признавшее Иисуса во время его бегства в Египет; во время крестного пути Иисуса осина не склонилась перед ним и не дрожала от жалости и сострадания; она дала свою древесину для изготовления креста, на котором был распят Христос; на осине удавился Иуда, предавший Иисуса Христа (Топоров 1988: 266).

Дальнейшее развитие темы дрожания Каина уводит в другую семантическую область: 'дрожать над деньгами' - ср. укр. дрижить як Каїн за алтин 'дрожит от жадности' (Юрченко-Івченко 1993: 63). Намек на жадность Каина содержится в словах Творца, адресованных будущему братоубийце: «Если будешь творить добро, жертва твоя будет принята, если же будешь творить зло, у порога твоего станет грех, а ты в своей алчности не сумеешь совладать с собой и впадешь в него» [курсив - И. К.] (Бт 4: 7).

За братоубийство «сделал Господь Каину знамение, чтобы никто, встретившись с ним, не убил его» (Бт 4: 15), чтобы был он изгнанником и вечным скитальцем на земле, - Каинову печать, знак преступления: в.-луж. ma na čole znamjo kaž Kain (САВКА 2002: 137); польск. jak gdyby na czole kładt znamię Kaina (SJPD).

Имя Каина фразеологически активно в русском языке: [погубить кого] как Каин; [восстать против кого] как Каин; [предать (ближнего)] как Каин; ${ }^{12}$ [маяться] как Каин [какой]; как Каин [какой] 'нести бремя проклятия,

${ }^{10}$ Польск. czysty jak Abel (NKPP 1: 4). Рус. убить как Авеля 'о невинной жертве' устарело: «Да, вы убиваете меня, как Авеля, зачем я принесла одни чистые плоды на жертвенник любви!» (А. А. Бестужев-Марлинский: Фрегат Надежда, 1833).

${ }^{11}$ Рус. трясется что (как) Каин (ДАль 4: 860); трястись /затрястись как (ровно) Каин (ССРЯ 2003: 156).

${ }^{12}$ Рус. убить (сгубить, предать, восстать против брата) как Каин может сохранять прямое значение 'о братоубийце' и приобретать переносное 'убить или предать ближнего': «И брата он, как Каин не убьет...» (В. Г. Бенедиктов: И ныне, 1859-1860); «...и никого нет у нас, чтобы заступиться за нас, а ты еще, как Каин, пошел против своего брата» (Г. А. Мачтет: И один в поле воин, 1886); «Ради добычи да грабежа и брательника своего, как Каин, сгубил - в кандалы заковал» (Ф. В. Гладков: Лихая година, 1954); «Какое мне будет счастье, когда я малых младенцев, ровно Каин, предам?» (С. П. Залыгин: Комиссия, 1976); «Перебили, говорил Строев, братьев по вере, убили их, как Каин Авеля» (В. Шаров: Воскрешение Лазаря, 1997-2002). 
мучиться, не находить на земле покоя' (Огольцев 2001: 232); скитаться [no cвету] как Каин ${ }^{13}$ 'менять место пребывания, быть внутренне неудовлетворенным и неспокойным; мучиться, не находить на земле покоя'. В части сравнений имя Каин синонимично слову проклятый: [работать] как Каин [какой] 'не давая себе отдыха, не переставая (работать, трудиться и т. п.)'; сидеть как Каин [какой] 'об обреченно и бездеятельно сидящем человеке' (ССРЯ 2003: 156); дергать кого вроде Каина 'о чьем-л. дергающемся, нервном лице'; новосиб. (рыбу добывать, работать) как Каин на море 'об изнурительной, крайне тяжелой и опасной работе (особенно морской добыче рыбы)' (БСРHC 2008: 239). Чеш. divá se jako Kain (ZAORÁLEK 2000: 459) имеет семантику 'смотреть очень злобно, враждебно, с ненавистью'.

О высшей степени отторжения имени Каина от библейского текста свидетельствует его активное употребление в народных сравнениях - особенно в сочетании с компонентами, обозначающими реалии быта (орудие труда, название старинной российской монеты татарского происхождения), место действия (море), словами разговорного стиля - и переход его в разряд апеллятивов. Можно заметить, что эквивалентных компаративизмов с этим онома (за исключением русского и украинского со значением 'дрожать от страха') у славян нет.

Апеллятив от имени Хам встречается в белорусской пословице Да людзей як пан, а у хацее як хам 'о приветливом на людях, но грубом дома человеке’ (Сцяшковгч 1983: 630). По Библии, Хам - один из сыновей Ноя, который посмеялся над наготой отца, за что был им проклят, а его потомки обречены на подневольный рабский труд. Одно из значений апеллятива в русском языке - 'грубый и наглый человек' (МЛТ 2010: 490-491). Болг. пръснати/ разпръснати (ходи) като хамово [mо] семе [= рассеяться как хамово семя] 'в разные места; навсегда' (КювлиЕВА-МишАЙковА 1986: 187, ФРБЕ 1: 514) связано с библейским повествованием о сыновьях Хама и их потомках, расселившихся после потопа по всему свету (Бт 10: 6-20).

Библейский Ирод, правитель Иудеи, стал синонимом тирана, мучителя, изверга: узнав о рождении «царя иудейского» Иисуса, он «послал избить всех младенцев в Вифлееме и во всех пределах его, от двух лет и ниже»

${ }^{13}$ Русское сравнение, частотное до первой трети XX в., встречается в текстах: «Беги из стороны родимой, / Скитайся грустным пришлецом, / Как Каин, господом гонимызй!» (Е. Бернет: «Тебе здесь места нет теперь...», 1837); «...Евгения Петровна подсела ко мне и очень серьезно и тихо начала говорить, что зачем-де я таскаюсь по белу свету как отчужденный от людей, будто Каин какой...» (И. А. Гончаров: Письма, 1842-1859); «Зато и прошатались они всю жизнь свою как Kaины, с печатью отвержения на челе...» (Н. И. Греч: Записки о моей жизни, 1849-1856); «...ведь на этой земле выросли, отцы наши тут лежат, маемся мы по све$m y$, как Kauнbl, и угла не найдем» (Н. Г. Гарин-Михайловский: Несколько лет в деревне, 1892); «Будь проклят, виновник моего позора! Скитайся вечно, как Каин! Много раз ты будешь гибнуть и не погибнешь» (Б. А. Садовской: Карл Вебер, 1923); «Тебе бы, Емельян, атаманом быть. Удали в тебе много, только какой-то нескладный ты, непоседливый... Слоняешься, как Каин» (В. Шишков: Емельян Пугачев, 1938-1945); «Тяжело мне очень. Как Каин бесприютный... Я бы хотел поскорее... покончить все разом» (Н. С. Лесков: Некуда, 1864). 
(Мф 2: 16). Еще четвертовластник казнил Иоанна Крестителя, убил Иакова, бросил в темницу Петра, которого «избавил... из руки Ирода» Ангел Господень. Отсюда сравнения: бел. трасетца як [mэй] Ірод 'о злобном человеке в гневе' (СБНП 2011: 176); рус. как Ирод (ирод) 'о крайне жестоком, злобном, бессердечном мучителе и садисте’ (ССРЯ 2003: 152, БСРНС 2008: 235); жестокий как Ирод 'очень жестокий' (PAVLASOVÁ 2013: 60); польск. zły jak Herod 'очень злой' (NKPP 1: 783); чеш. krutý jako Herodes (ГРенАРОВА 2006: 736); být krutý (ukrutný) jako Herodes 'о крайне бесчеловечном, жестоком, лютом человеке' (РAVLASOVÁ 2013: 60). Рус. смотреть (глядеть) как на Ирода (ирода) имеет семантику 'смотреть на кого-л. с ненавистью, мстительно или с ужасом, страхом и отчаянием' (ССРЯ 2003: 152, БСРНС 2008: 235). В карельских говорах есть сравнения как аред - 1. 'о жестком человеке', 2. 'о вредном, злом человеке' (БСРНС 2008: 22), где просторечное Аред ${ }^{14}$ «то же, что ирод; дряхлый, зловредный старик, брюзга; скряга. В народной речи имя Иаред было переосмыслено под влиянием другого библейского имени - Ирод» (БСРНС 2008: 22). «Отрицательная оценочность переносного значения может быть связана со звуковой ассоциацией со словами Ирод и скаред. Ср. поговорку: Рассылься аредом, да не доставайся скаредам» (МЛТ 2010: 52). Ср. также «перекличку» этих имен в карел. работать как аред 'об исступленно, яростно, страстно работающем человеке' (БСРНС 2008: 22) и в строках: «Я работаю, как ирод, оглашенно, едва успеваешь думать» (С. Буданцев: Мятеж, 1919-1922). В русском языке апеллятив ирод является также бранным словом. «За все содеянные злодеяния его постигла божья кара: царь Иудеи был поражен страшной болезнью и, быв изъеден червями, умер» (Деян 12: 23). Видимо, именно этим библейским строкам обязано своим происхождением чеш. smrdět jako Herodes 'очень неприятно пахнуть, вонять, смердеть' (SČFI 1983: 110). Чешскому языку было известно и сравнение býti něčeho prázden jako Herodes 'не мочь сделать что-то; быть неспособным к каким-л. действиям, решениям, идеям' (РAVLASOVÁ 2013: 74). Варианты его (být čeho prázden jako Josef Herodesa; byl jsem toho prázden co Josef Herodesa) зафиксированы Патриком Оуржедником (см. OUŘEDNík 1994); эти архаичные фразеологизмы встречаются в литературе с 1530 г. (PAVLASOVÁ 2013: 74). Heпосредственно с евангельскими строками «И сделались в тот день Пилат и Ирод друзьями между собою, ибо прежде были во вражде друг с другом» (Лк 23: 12), связаны чеш. smíŕit se (smířriti sě) jako Herodes s Pilátem; smírili sě jako Herodes s Pilatem; s ním se i smieřili jako Herodes s Pilátem o Ježíše 'вступить в альянс' (PAVLASOVÁ 2013: 116). В укр. врода як в Ірода 'внешняя непривлекательность' (Тимошик 2007: 107) разнокоренные сходнозвучные слова сочетаются с рифмой.

Библейские корни (Книга Есфирь ветхозаветного канона) имеют устойчивые сравнения: бел. біці каго як Гамана (ЗНС 1975: 137); укр. б’ють як Гамона (гамана) (Номис 1993: 201, Юрченко-Івченко 1993: 35, ДоБРОльОжА

${ }^{14}$ Первоначально - библейский патриарх Иаред, проживший 962 года. 
2003: 47); битий як гаман (ФРАнКо 1: 312, ДоБРОльОЖА 2003: 47); лемк. бити як гамана (ВАРХОЛ-ІВченко 1990: 37); польск. bity jak Aman (Haman) (NKPP 1: 776); bije jak hamana (SJPD). Аман - всемогущий царедворец персидского царя Ксеркса (в Библии - Артаксеркс) - невзлюбил Мардохея, не падавшего перед ним ниц, несмотря на приказ царя (Есф 3: 2). Его высокомерие, заносчивость дали жизнь в.-луж. kottny kaž Haman 'очень горделивый' (IVČENKOWÖLKE 2004: 71). Но Аман был бессилен против Мардохея, пользовавшегося при дворе большим влиянием и личным покровительством царя: дежуря однажды у дверей царской опочивальни, Мардохей из подслушанного разговора узнал о готовящемся убийстве Ксеркса и предупредил о нем царя через свою родственницу и воспитанницу Есфирь, любимую жену Ксеркса, ставшую царицей. Заговорщики были повешены на дереве, Мардохей снискал еще большее доверие и расположение царя, а в памятной книге была сделана запись о спасении Мардохеем жизни царственной особы (Есф 2: 7, 17, 2123). В свое время Есфирь утаила по совету Мардохея от царственного супруга, что она иудейка и родственница Мардохея, переселенного из Иерусалима вместе с пленниками (Есф 2: 6, 10). Случайно узнав об этом из доноса, Аман решил отомстить Мардохею. Он добился у царя приказа о поголовном истреблении живущих в Персии иудеев, так как они сохранили свои религиозные обряды и обычаи; при этом Аман пообещал вложить в царскую казну десять тысяч таланов серебра (Есф 3: 8-11). По просьбе Мардохея после трехдневного поста и молитв Есфирь решилась ходатайствовать перед супругом за обреченных евреев. Она незваной явилась к Ксерксу (за это ей грозила смертная казнь: в царских гаремах у персов женам запрещено было без зова входить в покои господина) и пригласила его с Аманом на пир. В это время по совету своей жены и друзей Аман приказал соорудить виселицу для Мардохея высотой в пятьдесят локтей (Есф 5: 1-14). Данный мотив запечатлен в в.-луж. wysoki kaž Hamanowa šibjeńca 'очень высокий' (RADYSERB-WJELA 1902: 266, IVČENKO-WÖLKE 2004: 339). Ночью Ксерксу не спалось, и он велел читать ему памятную книгу, где была запись о том, как Мардохей спас ему жизнь. Царь решил вознаградить верного слугу. Утром, когда Аман явился к Ксерксу для утверждения приказа о казни Мардохея, царь спросил его, как надлежит поступить с человеком, которого хочешь особо отличить. Уверенный, что речь идет о нем, Аман ответил, что такого человека следует провезти по городу в царском одеянии верхом на царском коне. В результате, в соответствии со своим же советом, Аман вынужден был воздать эти почести своему врагу - Мардохею (Есф 6: 1-11). Едва он вернулся домой, как пришли евнухи с приказом явиться на царский пир. На пиру Есфирь призналась супругу, что она иудейка, и попросила отменить указ об уничтожении ее единоверцев. Осознав всю подлость Амана, царь в гневе вышел в сад, а вернувшись, застал своего царедворца припавшим к ложу Есфири (он умолял царицу о заступничестве перед Ксерксом). Решив, что Аман насилует царицу, Ксеркс приказал повесить его на виселице, предназначенной для Мардохея (Есф 7: 1-10) и удовлетворил просьбу своей супруги: разрешил 
иудеям отомстить своим врагам по всей Персии. В итоге погибло 75 тысяч человек и среди них - десять сыновей Амана. Назначенный на место Амана Мардохей разослал по областям письма, отменяющие избиение иудеев, и призвал иудейские общины ежегодно торжественно отмечать праздник Пурим - день, когда решилась судьба иудеев (выбирая день для истребления еврейского народа, Аман бросал жребий - пур) (Есф 7: 20-32; 9: 24, 31).

Однако, как справедливо отмечает А. А. Ивченко, происхождение этих устойчивых сравнений нельзя выводить непосредственно из библейского текста; «их возникновение - результат обсервации украинцами, белорусами, поляками традиционного поведения евреев во время празднования Пурима» (Івченко 1996: 92), установленного в честь спасения евреев от заговора Амана, когда инсценируется его избиение и повешение. Аман - действующее лицо еврейского праздника Пурим - объект для насмешек и символического избиения: «В этот день дети бьют палками по земле, то есть „бьют“ Амана... и кричат, будто насмехаясь над Аманом» (ВинеР 1895: 61). В дни празднования Пурима в синагогах читается сува Эстер; при произнесении имени Амана чтение прерывается криками, шумом, тарахтением, производимым трещотками. Это необычное для христиан поведение во время Пурима отражено в сравнениях: бел. гармідар, баџџ̧э жыды гамана б'ющь 'о громкой брани, крике, сильном шуме’ (СЕРжпутоўскі 1998: 274); накінуцциа на каго як жылы на гамана 'наброситься безжалостно' (СЕРжпУтоўскі 1999: 2); таўчьл каго яко бы гамана 'безжалостно бить' (СБНП 2011: 108); піхаџьь як амана 'унижать, позорить' (Цыхун 1993: 12); крычаџь як на гамана 'беспричинно кричать'; напасиі (наваліщ̧иа) на каго як на гамана [якогась] 'безосновательно напасть на кого-л.' (Носович 1870: 108, FEDEROWSKI 1935: 102, СБНП 2011 : 107); [напасиі] як жыды на гамана (ФСМТК 1993: 191); укр. товчуть як жиды Гамана (гамана) (КомАРов 1890: 8, СУМ 1: 269); кляне як жиды гамана; б’ють як жид гамана (ДоБрольожА 2003: 36, 47); польск. zbili go jak Żidzi Hamana; jak na Hamana krzyczeć (krzyczycie jak na hamana); jak na Hamana nastawać (NKPP 1: 777, SJPD).

Слово гаман имеет в украинском языке значения 'еврейский праздник Пурим', ср.: Гаман не свято, трясия не хороба (Номис 1993: 263 ) и 'действующее лицо этого праздника, изображающее Амана и используемое евреями в качестве объекта для насмешек и безжалостного поведения’ (СУМ 1: 269, MHC 1: 136), а также 'соломенное чучело, которое во время Пурима бьют евреи’ (ДоБРОльожА 2003: 156). Это обстоятельство, а также забвение библейской истории Амана, дало жизнь украинским компаративизмам б'ють, так як жидівського Гамана (Гамона) (Номис 1993: 201); битий як жидівський гаман (ФрАнко 1: 312) - напомним, что Аман был не иудеем, а персом.

Многие народные сравнения не функционируют в статичной форме. Иногда трудно решить, каким приемом трансформации образован фразеологизм. Украинское сравнение б'ють як гаманову козу 'сильно, безжалостно

${ }^{15}$ Апеллятив с семантикой ‘презираемый человек’, ‘злой’ (Носович 1870: 108). 
бить кого-л.' (ДоьРольожА 2003: 10) могло возникнуть путем контаминации синонимичных б'ють як Сидорову козу и б'ють як жидівського гамана или в результате замены отономастического прилагательного в известном восточным славянам сравнении: бел. лупіuъ як сідараву казу; укр. обідрав (облупив, надув) як Сидорову козу; набився як Сидорової кози; бити /побити (дерти, лупить, лупцฺювати /відлупџювати, латати и пр.) як Сидорову (сидорову) козу; рус. бить / избить (побить, драть/выдрать, отодрать, пороть /выпороть, сечь/высечь, лупить /отлупить, брянск. облупить, отлупиевать, доить) как Сидорову (сидорову) козу (имя Сидор и библейское имя Аман экспрессивны и отрицательно окрашены). Фразеологизмы с компонентом коза на славянском ареале имеют варианты: рус. драть как антонову козу; орл. лупить как козу; перм. лупить как козу брянскую; чеш. drát (zkopu, zbit, zmalovat, zmlátit, ztřiskat) jakfinanc [= сборщик налогов] kozu; слвц. drát'। zdrát' ako financ kozu; польск. wyrychtowat jak diabet koze - ср. латыш. pērt ka kaiminu āzi [= как соседскую козу], что «показывает, что его исходным вариантом был оборот бить (драть) как козу» (БМС 2005: 311), образованный по продуктивной структурно-семантической модели «бить + как + домашнее животное»: рус. бить / избить как скотину (скотинку, собаку, ломовую лошадь); укр. б’ють як кота; побити (прибити) як кішку ([шкодливого] кота); набився (налупивсь) як голої вівці (овечки); побити як собаку; лемк. бити як скотину; збити як пса; болг. бия/пребия като животно (добиче); пребия като куче (мръсно коте); макед. бие/пребие (mепа/nретепа) како куче (мачка, маче); серб. тући као вола у купусу; хорв. mlatiti/izmlatiti (namlatiti, tući/istući) kao vola u kupusu [= как вола в капусте]; istući (pretući, prebiti) kao psa (mačku); слвн. mlatiti/zmlatiti (namlatiti, tepsti / pretepsti) kot psa (mačka, vola); чеш. bit/zbit (řezat/sařezat) jako psa; слвц. mlátit'/zmlátit' (bit'/zbit', nabit') ako koňa (psa); польск. bić/zbić (ttuc/zattuc) jak psa - cp. финск. piestä (lyödä) kuin vierasta sikaa [= бьют как чужую свинью] и пр. Ср. также польск. bije jak hamana (SJPD), где haman 'большая неуклюжая лошадь, тяжеловоз' (БПРС 1980: 258); 'большое тяжелое и неуклюжее чудовище (обычно о лошади)' (SJPD). Видимо, это же значение слова реализуется и в лемк. робити (драти) як гаман 'очень тяжело работать' (ВАРХол-Івченко 1990: 37).

Укр. товче як чорт гамана (ДоБрольожА 2003: 49) отражает древние религиозно-мифологические представления славян: в условиях христианскоязыческого двоеверия народная демонология приравнивала иноверцев к нечистой силе. Апеллятив развивает также семантику 'нечистая сила': бел. зль $я \kappa$ геман ${ }^{16}$ які 'о жестоком человеке' (РАСтоРгуЕв 1973: 78); укр. товчеться як гаман у пеклі ${ }^{17}$ “пребывает в постоянных хлопотах' (ДоьРольожА 2003: 56).

Заметим и то, что фразеологизмы с именем данного персонажа и апеллятивами от него распространены в зонах кучного проживания иудеев. Для

${ }^{16}$ Слово имеет семантику ‘злой дух', ‘злой человек'; восходит к имени Гаман.

${ }^{17}$ Ср. укр. хидить як дідько [=черт] по пеклу [=ад]; товчеться як чорт у попелі (ЮрчЕНКО-ІВчЕНКО 1993: 47, 164); серб. кубури као ђаво у паклу 'возится как дьявол в пекле' (КАРАџИЋ 1849: 162); польск. tluć się jak diabet po piekle (SKORUPKA 1: 170) с той же семантикой. 
русского языка библеизм Аман лакунарен, он встречается у классиков еврейской литературы с пояснением компаративизма: «Пусть критикуют, пусть смеются, пусть хоть на стену лезут - боюсь я их, как Аман трещзотки» ${ }^{18}$ (Шолом-Алейхем: Праздношатающийся).

О главном герое новозаветных сказаний мы уже писали (см. КузнецовА 2014), поэтому в данной статье приведем те устойчивые сравнения, которые не были в ней рассмотрены. Это белорусские компаративизмы (насмешл.) як Icyc Xрыстос распяты 'о нестриженом парне' (СБНП 2011: 233); барада не раўнуючы як у Пана Езуса на абразе [= икона] 'об аккуратно подстриженной бороде' (VARŁYна 1970: 80); сядзець як Cnac ${ }^{19}$ 'о человеке, бездеятельно сидящем в полном достатке' (FEDEROWSKI 1935: 287). С сюжетом предательства Иудой своего Учителя связаны бел. прадаць як Юда Хрыста; прадаць Хрыста нібы Юда 'о предателе, изменнике' ${ }^{20}$; адвярнуц̧ца як Юда ад святой вячэры 'о человеке, который от чего-л. отказался или нечто предал' (СБНП 2011: 477); здрадны (здрадлівы, прадажны) як Юда (Янкоўскі 1973: 73, 129); укр. вірний як Іуда в середу (ДоБРольожА 2003: 25); юдит на мене як той Юда Скаріотський (Скаріоцький) 'о клеветнике' (зафиксировал И. Франко, цит. по ГРОм 2004: 83, САВКА 2002: 143); лемк. як Юда Шкарігодскый 'підлый, підступный' (ВАРХОЛ-ІВчЕНКО 1990: 148). ${ }^{21}$

Негативное восприятие этого библейского образа христианами отразилось и в народных представлениях о внешности Иуды: болг. грозен като Юда 'очень некрасивый'; кривя се като Юда 'перекоситься (о лице человека)',22 (КювлиЕВА-МишАЙковА 1986: 127, 153); польск. rudy jak Judasz 'о рыжеволосом'; ср. англ. Judas hair [= Иудины волосы] 'рыжие волосы' (BD 1994: 514); венг. vörös, mint a Júdás haja 'рыжий как волосы у Иуды' (O. NAGY 1976: 320). По апокрифической легенде, Иуда родился с рыжими волосами, а рыжеволосым христианизированные народы приписывали злой нрав (БЕловА 1995: 217), считали лгунами, трусами, предателями, что отражено в русских пословицах Рьжнй да красный, человек опасный; С рыжим дружбы не води, с черным в лес не ходи; Рыжих и во святых нет (Даль 3: 1755).

${ }^{18}$ В канун праздника в синагогах читают «Свиток Эстер» и при каждом упоминании имени Амана стучат трещотками.

${ }^{19}$ Изображение Спасителя на иконах.

${ }^{20}$ Вычленяется из текстов: «Пазнейшая літаратура прадоўжыць галерэю тыпаў, падобных Гаршчку і Жабіну (з апавядання таго ж Гарэцкага „Апостал“), пакажа сапраўдных пярэваратняў, людзей карыслівых і няшчырых, гатовых у імя кар'еры і самазахавання адмовіцца ад прозвішча бацькоў, прадащь іх, як некалі Юда прадаў Хрыста» (BelSoch.by, 2009); «Яны хочуць, каб ён забіваў людзей. Каб прадаў Хрыста, нібы Юда, і стаў забойцам, прысягнуў, што згодны на гэта» (А. Кудласевич: Пятро, грузи жыта!, 2010).

${ }^{21}$ О других компаративных оборотах с именем библейского предателя см. КузнЕцОВА 2015: 71, КУЗНЕЦОВА 2016: 58.

22 После предательства Иисуса Иуду постигла Божья кара: его уста перекосило, и он стал некрасивым, безобразным, косоротым. Здесь проявляется и семиотически значимая культурная константа-символ, берущая начало еще в мифопоэтическом сознании и связанная с идеей нечистого, - кривизна. Не случайно, видимо, Иоанн, повествуя о предсказании Иисусом предательства Иуды, упоминает о том, что «вошел в него сатана» (Ин 13:27). 
Образ Богородицы ассоциируется в основном с позитивом: бел. як Mamка Божжая 'о приветливой, милосердной женщине' (ЮрчАнкА 1977: 190); укр. добрий як пресвята богородиия (Гурин 1974: 68); рус. улыбаться как Богоматерь ${ }^{23}$; серб. искрен као Мајка божија (Вуловић 2014: 41, Стошић 2007: 78). Она красива: рус. красивая как Мадонна ${ }^{24}$ 'об идеально, возвышенно и недоступно прекрасной женщине' (ССРЯ 232); чеш. být krásná jako Panenka Marie; (být) krásná jako madona (PAVLASOVÁ 2013: 155); слвц. pekná ako Panenka Mária (SNK); je krásna ako Madona ${ }^{25}$ (FS 1996: 28); хорв. lijepa kao djevica Marija (MenAC-Miнalić 2003-2004: 369). Богоматерь в народных представлениях живет спокойной, полной достатка жизнью: сиб. жить как богородииа (СДФ 1980: 148); оберегает от всяческих бед: сиб. жить как за богородицей ${ }^{26}$ (СДФ 1980: 148); поэтому в народе ее почитают: рус. обожать кого как пречистую деву-богородииу 'испытывать чувство возвышенной, идеальной, доходящей до преклонения любви’; молиться кому как богородиuе 27; чеш. kouká jako na Panenku Marii (ZAORÁLeK 2000: 500); obdívovat jako na Panenku Marii (SČFI 1983: 252); kouká se (divá se) jako na panenku Marii; hledět (divat se) jako na Pannu (Panenku Marii) 'смотреть благоговейно, преданно, с большой любовью’ (PAVLASOVÁ 2013: 163). Изображением Богородицы на иконах мотивировано бел. сядзещь як Мацер Божая 'о ком-то, кто сидит со сложенными руками’ (БПФС 2000: 27). Иногда имя Божьей матери может употребляться с оттенком иронии: «Как дева Мария, - родить без власти законы, - усмехнулся Брусенков» (С. Залыгин: Соленая Падь, 1967) и приобретать негативные коннотации: слвц. tvárit' sa ako Panenka Mária 'притворяться добрым, непорочным'28 (MATOLÁкOVÁ 2013).

Межъязыковое сопоставление выявляет расхождения внутренней формы, свойственные прежде всего имплицитным библейским фразеологизмам, когда в разных языках в качестве основы номинации избираются различные

23 Сравнение может относиться и к лицу мужского пола: «Яковлев съедал два яблока и засыпал до следующего утра, ульбаясь нежно и всепрощающе, как Богоматерь» (Е. Радов: Змеесос, 2003).

${ }^{24}$ Мадонна (из итал. та donna 'моя госпожа') - название Богоматери у католиков, возникшее в эпоху средневековья из молитвенного обращения к Богородице; перен. 'о женщине, являющейся воплощением целомудрия и красоты' (МЛТ 2010: 302).

${ }^{25}$ Сравнение известно и неславянским языкам: англ. to be as beautiful as the Virgin Mary; нем. schön wie eine Madonna sein; фp. être belle une madone (PAVLASOVÁ 2013: 155).

${ }^{26}$ Сравнение реализует народное понимание хорошей жизни под защитой Господа и Богородицы; ср. бел. жыцыь як за богам (САнько 1991: № 804).

27 Такие, значит, правила у господ: «хоть какая будь жена, а он должен обожать ее, как пречистую деву-богородицу» (А. С. Новиков-Прибой: Капитан первого ранга, 1936-1944); «Я не знаю, если люди как следует будут молиться Собчак, как Богородице, то сможет ли она реализовать то, о чем пели Pussy Riot, и то, о чем мечтает оппозиция» (А. Ахмадиева: Ксения Собчак примерила на себя образ Богородицы. Известия, 13.09.2012).

${ }^{28}$ В хорватском языке это же значение выражается фразеологизмами glumiti blaženu djevicu Mariju [букв. glumiti ‘играть’ (как актер/актриса в театре); представлять (строить) из себя блаженную деву Марию]; misliti da je tko djevica Marija [думать, что кто-то дева Мария]; praviti se djevica Marija [притворяться девой Марией] (МеNAC-MiнALIĆ 2003-2004: 368). 
моменты одного сюжета; в результате возникают разные по внутренней и внешней форме фразеобиблеизмы. Младший сын из евангельской притчи отправился странствовать, «расточил имение свое, живя распутно», затем, раскаявшись, вернулся в отчий дом и покаялся в содеянном. Эта история во фразеологии православных христиан привела к появлению субстантивных оборотов бел. блудны сын; укр. блудний (блудящзий) син; рус. блудный сын ${ }^{29}$; серб. bludni sin; болг. блудният сuн. В фразеологии католико в актуализируются иные черты ситуации и в основе метафорического переноса и номинации лежат другие признаки - расточительство, мотовство: укр. марнотравний син; бел. марнатраўны сын; польск. marnotrawny syn; кашуб. [to je] marnotrôwny syn; чеш. marnotratný syn; слвц. márnotratný syn; хорв. rasipni sin; англ. [the] prodigal son и неспособность исправиться: хорв. izgubljeni sin, чеш. ztracený syn; нем. der verlorene Sohn.

На базе этого фразеологизма возникли сравнения: бел. вяртащчца / вярнуцица як блудны сын [дамоў] ${ }^{30}$; укр. як блудний син; вернутися/повернутися як блудний (марнотравний) син ${ }^{31}$; рус. возвращзаться/вернуться [домой, в дом] как блудный сын ${ }^{32}$; болг. връщчам се/върна се (завръщзам се/завърна

${ }^{29}$ В текстах актуализируются значения: 1. 'беспутный, нравственно нестойкий, легко поддающийся соблазнам человек'; 2. 'человек, покинувший свой дом, а затем вернувшийся'; 3. 'раскаявшийся в своих ошибках, заблуждениях и прегрешениях и вернувшийся к разумной жизни человек’; 4. 'человек, надолго исчезнувший, а потом неожиданно появившийся'.

${ }^{30}$ Встречается в текстах: «А ў мае песні пачынаюць залятаць / Чужыя птушкі, воблакі, вятры / і параўнанне: / Як блудны сын, вяртаюся дамоў» (М. Танк: Вяртанне); «Так, новым этапам майго жыцця стала праца ў хоры Нацыянальнага акадэмічнага Вялікага тэатра оперы і балета Рэспублікі Беларусь. А праз пяць гадоў я, як блудны сын, вярнуўся ў Музычны тэатр» (ПРОХАРАў 2011: 127-128).

31 «Джонатан. Вона (мати) надіється, що ти не прийдеш, Як блудний син... Річард. Вона сказала так? Джонатан. Вона се говорила при громаді» (Леся Українка: Твори. Т. 3. 1952. 105); «Мухтарова! Саїда Алі Мухтарова! - заревло в численній тепер масі. Саїдові було незручно перед представниками з центру. Він тепер як блудний син, і раптом йому така увага» (Іван Ле: Роман міжгір'я, 1953); «я перебув той великий проклін, який кидає природа на своїх марнотравних дітей, та тих, що виреклися іiї і пішли шукати інших богів. Я вернувся до неї, в покоpi, як марнотравний син» (ЛЕпкий 1991: 506); «[Жанна:] Ну, ваш милий Петрусь дуже швидко повернеться до вас, як блудний син, без копійки i, можливо, без піджака» (Олександр Корнійчук: Чому посміх. зорі, 1958); «На його думку, „Росія, як блудний син, повинна повернутися до Європи, в іудо-християнську сім’ю народів“”» (http://fakty.ictv.ua/ua/ukraine/polituka/201109161430299).

32 «А если, жизнью смят, обманутый мечтами, / К тебе, как блудный сын, я снова возвращусь, - / Кого еще найду меж старыми друзьями / И так ли с новыми сойдусь?» (А. Н. Апухтин: Прощание с деревней, 26.06.1858); «Я написал тогда об идеалах народа и о том, что мы, «как блудные дети, возвратись домой, должны преклоняться перед правдой народной и ждать от нее лишь одной мысли и образа» (Ф. М. Достоевский: Дневник писателя, 1876); «Так раздумывая сама с собой, Дуня, решила во что бы то ни стало покинуть луповицкий корабль людей божьих, отречься от их неправедной веры, во всем и навсегда разорвать с ними и, как блудный сын, возвратиться в дом отчий» (П. И. Мельников-Печерский: На горах, 1875-1881); «Мне, право, кажется, да и другие как бы на это намекают, что я, как блудный сын, вернулся домой» (Б. Б. Голицын: Письма, 1893); «И он входит теперь в новую силу, он, как блудный cын, из скитаний по идейным чужбинам, возвращается теперь в родное ему лоно славяно- 
се) като блудния син (КювлиЕВА-МишАЙКОВА 1986: 114); лемк. піти як блудный сын 'бесследно пропасть' (ВАРХОЛ-ІВченкО 1990: 121).

Как видим, рецепция персонажей и сюжетов Библии и апокрифической литературы часто различается. В результате актуализируются различные черты, качества и т. п. одного и того же образа Священного Писания, проявляется неодинаковый интерес к описываемой ситуации. Это приводит к появлению дополнительных или отличающихся от присущих библейским персонажам ассоциаций, создает расхождения в плане содержания и внутренней формы устойчивых сравнений.

Хотя само имя библейского героя интернационально, устойчивые сравнения с ним таковыми являются не всегда. Сопоставление фразеологических библеизмов в плане содержания выявляет единицы, не имеющие семантических аналогов в других языках или ареалах. Псевдобиблейские и часть эксплицитных сравнений, ярко иллюстрируя культурно-национальное своеобразие восприятия персонажей Священного Писания тем или иным народом, «показывают радиус действия Библии, глубину ее проникновения в ткань языка и мышления данного этноса, иллюстрируют его отношение к миру прошлого и настоящего» (CHLEBDA 1997: 70), составляют частицу «духа языка», демонстрируют идиоэтничное в сфере фразеологии. Национальное своеобразие встречается как на уровне иной образной основы: укр. труситься як Каӥн - рус. трястись как Иуда (В. Осеева: Динка прощается с детством, 1969), так и на уровне безэквивалентных фразеологизмов: укр. вона як біблійна Pуф ${ }^{33}$ (АЛЕФИРЕнко 1978: 65), так как одни сюжеты могут быть в одном языке активны, в другом - периферийны или лакунарны.

фильского национализма и православия» («Суд» над Розановым, 1914); «Как блудный сын на зов отеческий, / И я в одиннадцатый час / Вернулся к жизни человеческой, / А мертвый самовар угас» (Б. А. Садовский: Н. И. Садовской, 1929); «К тебе, народ многострадальный, / И к вам, цветы моих долин, / Порой весны, порой Пасхальной / Вернулся я, как блудный сын» (С. М. Соловьев: «К тебе, народ многострадальный...», 1918-1929); «Внезапная смерть старого князя смягчила сердца богов, и Сергей Мятлев, словно блудный сын, вернулся под кавалергардский кров» (Б. Окуджава: Путешествие дилетантов. Из записок отставного поручика Амирана Амилахвари, 1971-1977); «Как блудный сын, я возвращаюсь к тебе каждый раз, мама» (Л. Утесов: «Спасибо, сердце!», 1982); «Здесь я как блудный сын, вернувшийся домой...» (А. Бовин: Пять лет среди евреев и мидовцев, или Израиль из окна российского посольства, 1999); «Там продвинутое „прогрессорское“ сознание сталкивалось с Неведомым в космосе, но герой, как блудный сын, мог вернуться домой к знакомому с детства озеру и приклонить голову к ногам отца у порога родного дома» (И. Сухих: Однажды была земля. Звезда, 2002).

${ }_{33}^{3}$ История Руфи-моавитянки, женщины добродетельной, сострадательной и трудолюбивой, излагается в Книге Руфи ветхозаветного канона. Перенеся все невзгоды и тяготы жизни, она не утратила своих положительных качеств и в награду за свое благородство и человеколюбие дожила до дней царствования своих потомков - Давида, ставшего величайшим героем израильского народа, и Соломона, прославившегося своей мудростью. 


\section{Литература}

АЛЕФИРЕНКО 1978 = АЛЕФИРЕНКО Н. Ф. Структурно-семантический анализ компаративных фразеологизмов современного украинского языка. Диссертация кандидата филологических наук. Киев, 1978.

БЕЛОВА 1995 = БЕЛОВА О. В. Иуда. В кн.: Славянская мифология. Энциклопедический словарь. Москва: «Эллис лак», 1995. 216-218.

БЕЛОВА 1999 = БЕЛОвА О. В. Каин и Авель. В кн.: Славянские древности. Т. 2. Москва: «Международные отношения», 1999. 436-437.

БЕТЕХТИНА 1999 = БЕТЕХТИНА Е. Н. Фразеологизмы с библейскими именами. СанктПетербург: «Издательство Санкт-Петербургского университета», 1999.

БМС 2005 = БИРИХ А. К., МОКИЕНКО В. М., СТЕПАНОВА Л. И. РУсская фразеология. Историко-этимологический словарь. Москва: «Астрель», «АСТ», 2005.

БНМ 1968 = Икономов Н. И. (ред.) Балканска народна мъдрост. Успоредици на български, сръбски, турски, румънски, гръцики и албански пословищи и поговорки. София: «Издателство на българската академия на науките», 1968.

БПРС 1980 = ГЕССЕН Д., СТЫПУЛА Р. Большой польско-русский словарь. Т. 1. Москва: «Русский язык», Варшава: «Ведза Повшехна», 1980.

БПФС 2000 = AKSAMітоw A., CzURAK M. Stownik frazeologiczny białorusko-polski. Бeларуска-польскі фразеалагічны слоўнік. Warszawa: Instytut Sławistyki PAN, 2000.

БСРНС 2008 = Мокиенко В. М., НикитинА Т. Г. Большой словарь русских народных сравнений. Москва: «ОЛМА Медиа Групп», 2008.

ВАРХОЛ-ІВчЕНКО 1990 = ВАРХОЛ Н., ІВчЕНКО А. Фразеологічний словник лемківських говірок Східної Словаччини. Братіслава: «Словацьке педагогічне видавництво»; Пряшев: «Відділ української літератури», 1990.

ВАРЮХИНА 2002 = ВАРЮХИНА Е. И. Семантические преобразования библеизмов в народной речи под влиянием древних мифологических представлений. В кн.: $M a-$ териаль XXXI Всероссийской научно-методической конферениии преподавателей и аспирантов. Вып. 7. Санкт-Петербург, 2002. 30-32.

ВинЕР 1895 = ВинЕР Л. Еврейско-немецкие слова в русских наречиях. Живая старина $1895 / 1$ : 57-70.

Вуловић 2014 = Вуловић Наташа С. Фразеолошке јединице с религијским компонентама у српском језику. Докторска дисертација. Београд, 2014.

ГРЕНАРОВА 2006 = ГРЕНАРОВА Р. Фразеосемантическое поле «Характер человека» в устойчивых сравнениях с союзом как и с антропонимами. Rossica Olomucensia 44 (2005): 733-738.

Гром 2004 = Гром Г. Франкові Нагуєвичі. Дрогобич: «Відродження», 2004.

Гурин 1974 = Гурин І. Образне слово. Постійні народні порівняння. Київ: «Дніпро», 1974.

Даль = ДАль В. И. Толковый словарь живого великорусского языка. Т. 1-4. Москва: «Прогресс», «Универс», 1994.

Даль 1993 = Пословицы русского народа. Сборник В. Даля в трех томах. Т. 1. Москва: «Русская книга», 1993.

ДоБРОВОльский 1894 = ДоБРОВольский В. Н. Смоленский этнографический сборник. Ч. 3. Пословииьл. Санкт-Петербург, 1894.

ДоБРОЛЬОЖА 2003 = ДоБРОЛЬОЖА Г. Красне слово - як золотий ключ. Постіні народні порівняння в говірках Середнього Полісся та суміжних територій. Житомир: «Волинь», 2003. 
ІвчЕнко 1996 = Івченко А. Українська народна фразеологія: ареали, етимологія. Харків: «Око», 1996.

КАРАџИЋ 1849 = КАРАџИЋ ВУК СТ. Српске народне пословице. Беч, 1849.

КОМАРОВ 1890 = КОМАРОВ М. Нова збірка народних малоруських приказок, прислів'їв, помовок, загадок $i$ замовлянь. Одесса: «Типо-литогр. Е. И. Фесенко», 1890.

КузнЕцОвА $2012=$ КузнЕцОВА И. В. Адам и Ева в устойчивых сравнениях славян. Studia Slavica Hung. 57 (2012): 127-141.

КУЗНЕцОВА 2014 = КУЗНЕцОВА И. В. Языковая игра в библейской фразеологии разных языков. Studia Slavica Hung. 59 (2014): 337-351.

КузНЕцОВА 2015 = КузНЕцОВА И. В. Иисус Христос в устойчивых сравнениях христиан. Studia Slavica Hung. 60 (2015): 65-78.

КузНЕцОВА 2016 = КузНЕцОВА И. В. Персонажи Библии в словацких сравнениях (на фоне других языков). Studia Slavica Hung. 61 (2016): 45-67.

КЮвЛИЕВА-МИШАЙКОВА 1986 = КЮвЛИЕВА-МИШАЙКОВА В. Устойчивите сравнения в българския език. София: «Издателство на българската академия на науките», 1986.

ЛЕПЕШАЎ = ЛЕПЕШАЎ І. Я. Фразеалагічны слоўнік беларускай мовы. Т. 1-2. Мінск: «Беларуска энцыклапедыя», 1993.

ЛЕПкий 1991 = ЛЕПкий Б. Мій товариш. В кн.: ЛЕпкий Б. Твори у 2 mомах. Т. 1. Київ: «Дніпро», 1991. 494-507.

МАС = ЕВГЕНЬЕВА А. П. (ред.) Словарь русского языка. Т. 1-4. Москва: «Русский язык», 1985-1988.

МАсловА 2001 = МАсловА В. А. Лингвокультурология. Москва: «Академия», 2001.

МиХеЛЬСОН = МиХЕЛЬСОН М. И. Русская мысль и речь. Свое и чужое. Опыт русской фразеологии. Сборник образных слов и иносказаний. Т. 1-2. Москва: «Терра», 1994.

МЛТ 2010 = МокиЕнко В. М., Лилич Г. А., ТРОФимкинА О. И. Толковый словарь библейских выражений и слов. Москва: «АСТ», «Астрель», 2010.

МНС = ЖЕЛЕХІвСький Є., НЕДІльСькИй С. Малоруско-німеиький словар. Т. 1-2. Львів, 1886.

НБФР = НиколовА-ГъЛЬБОВА Ж. Немско-български фразеологичен речник. Т. 1-2. Пловдив: «Летера», 2001.

Номис 1993 = Номис М. (ред.) Українські приказки, прислів'я і таке інше. Київ: «Либідь», 1993.

Носович 1870 = Носович И. И. Словарь белорусского наречия. Санкт-Петербург: «Императорская Академия наук», 1870.

НУФС = Німецько-український фразеологічний словник. Т. 1-2. Київ: «Радянська школа», 1981.

ОГОЛЬЦЕВ 1994 = ОГОЛЬЦЕВ В. М. Краткий словарь устойчивых сравнений русского языка. Ижевск, 1994.

ОГОЛЬЦЕВ 2001 = ОГОЛЬЦЕВ В. М. СЛоварь устойчивых сравнений русского языка (синонимо-антонимический). Москва: «Русские словари», «АСТ», «Астрель», 2001.

ПАПАЗЯн $1987=$ ПАПАЗян А. А. Каин и Авель. В кн.: Мифы народов мира. Т. 1. Москва: «Советская энциклопедия», 1987. 607-609.

Попов 1976 = Попов Р. Н. Фразеологизмы современного русского языка с архаичными значениями и формами слов. Москва: «Высшая школа», 1976.

ПРОХАРАў 2011 = ПРОХАРАЎ А. «Не прапусціць момант...». Маладосиьь 2011/7: 126129. 
ПРФС = Гюлумянц К. Польско-русский фразеологический словарь. Т. 1-2. Минск: «Экономпресс», 2004.

РАСТОРГУЕВ 1973 = РАСТОРГУЕВ П. А. Словарь народных говоров Западной Брянщины. Мінск: «Навука і тэхніка», 1973.

САВКА 2002 = САВКА О. Фразеологія серболужицької, словацької та української мов з біблійним ономастичним компонентом. Lětopis. Časopis za rěč, stawizny a kulturu Łužiskich Serbow 2002/1: 131-147.

САНьКО 1991 = САНько 3. Маль руска-беларускі слоўнік прыказак, прымавак і фразем. Мінск: «Навука і тэхніка», 1991.

СБГ = Слоўнік беларускіх гаворак паўночна-заходняй Беларусі $і$ яе пагранічча. Т. 1-5. Мінск: «Навука і тэхніка», 1979-1986.

СБНП 2011 = Слоўнік беларускіх народных параўнанняў. Мінск: «Беларуская навука», 2011.

СДФ 1980 = ФЕдоРов А. И. Сибирская диалектная фразеология. Новосибирск: «Наука», 1980.

СЕРжПУТОўСК 1998 = СЕРЖПУТОўскі А. К. Прымхі $і$ забабоны беларусай-палешукой. Мінск: «Універсітэцкае», 1998.

СЕРжПУТОўСКі 1999 = СЕРжПУТОўСКі А. К. Казкі і апавяданні беларусай-палешукой. Мінск: «Універсітэцкае», 1999.

СОСВ 1997 = БлиновА О. И. (ред.) Словарь образных слов и выражений народного говора. Томск: «НТЛ», 1997.

ССРЯ 2003 = МокиЕнко В. М. Словарь сравнений русского языка. Санкт-Петербург: «Норинт», 2003.

Стошић 2007 = Стошић Љ. Библијске изреке и пословище. Београд: «Српска књижевна задруга», 2007.

СУМ = Словарь української мови. Т. 1-4. Упор. Борис Грінченко. Київ, 1907-1909.

Сцяшковгч 1983 = Сцяшковгч Т. В. Слоўнік Гродзенскай вобласизі. Мінск: «Навука і тэхніка», 1983.

Тимошик 2007 = Тимошик Г. Біблієконотоніми сучасної української мови у лінгводидактичному аспекті. Теорія і практика викладання української мови як іноземної. Вип. 2. Львів, 2007. 103-110.

Топоров 1988 = Топоров В. Н. Осина. В кн.: Мифы народов мира. Т. 2. Москва: «Советская энциклопедия», 1988. 266-267.

ФРАНКО = ФРАНКО І. Галицько-руські народні приповідки. Т. 1-3. Львів, 1901-1910.

ФРБЕ = НИЧЕВА К., СПАСОВА-МИХАЙЛОВА С., ЧОЛАКОВА Кр. Фразеологичен речник на български език. Т. 1-2. София, 1974-1975.

ФСМТК 1993 = Фразеалагічны слоўнік мовы твораў Я. Коласа. Уклад. А. С. Аксамітаў і інш. Мінск: «Навука і тэхніка», 1993.

ФядосІк 1979 = ФядосІк А. С. (рэд.) Выслоўі. Склад, сістэматызацыя тэкстаў, уступ, артыкул і камент. М. Я. Грынблата. Мінск: «Навука і тэхніка», 1979.

Цыхун 1993 = Цыхун А. П. Скарбы народнай мовы (з лексічнай спадчыны насельнікаў Гродзенскага раёну). Гродна: «Гродзенскі дзяржаўны ўніверсітэт», 1993.

ЮрчАНКА 1977 = ЮрчАНКА Г. Ф. Слова за слова. Устойлівыя словазлучэнні ў гаворках Мсціслаўшчыны. Мінск: «Навука і тэхніка», 1977.

ЮрЧЕНКО-ІвЧЕНКО 1993 = ЮрЧенКО О. С., ІвЧЕнКО А. О. Словник стійких народних порівнянь. Харків: «Основа», 1993.

Янкоўскі 1973 = Янкоўскі Ф. М. Беларускія народныя параўнанні. Кароткі слоўнік. Мінск: «Вышэйшая школа», 1973. 
BD 1994 = Brewer's Dictionary of Phrase and Fable. New York: Harper Perennial, 1994. BRAUNFELS 1990 = BRAUNFELS W. Lexikon der christlichen Ikonographie. T. 1. Rom-Freiburg-Basel-Wien: Herder, 1990.

Chlebda 1997 = ChleBdA W. Библия в языке - язык в Библии. In: Problemy frazeologii europejskiej II. Warszawa: Energeia, 1997. 67-74.

Federowski 1935 = Federowski M. Lud Bialoruski na Rusi Litewskiej. T. 4. Warszawa: Towarzystwo Naukowe Warszawśkie, 1935.

FINK 2006 = FINK ARSOVSKI Ž. Hrvatsko-slavenski rječnik poredbenih frazema. Zagreb: Knjegra, 2006.

FS 1996 = HABOVŠTIAKOVÁ K., KROŠLÁKOVÁ E. Frazeologický slovník. Človek a príroda vo frazeológii. Bratislava: Veda, 1996.

IVČENKO-WÖLKE 2004 = IVČENKO A., WÖLKE S. Hornjoserbski frazeologiski stownik Obersorbisches phraseologisches Wörterbuch-Верхнелужиикий фразеологический словарь. Budyšin/ Bautzen: Ludowe nakładnistwo Domowina, 2004.

MATOLÁKOVÁ 2013 = MAtoláKOVÁ A. Prekladová realizácia frazeologických jednotiek v biblických translátoch 1. Morfologicko-syntaktické posuny. Jazyk a Kultúra 15. Prešov, 2013. http://www.ff.unipo.sk/jak/cislo16.html.

MenaC-Minalić 2003-2004 = MenaC-Minalić M. Hrvatski dijalektni frazemi s antroponimom kao sastavnicom. Folia Onomastica Chroatica 12-13 (2003-2004): 361-385.

O. NAGY 1976 = O. NAGY Gábor: Magyar szólások és közmondások. Budapest: Gondolat, 1976.

NKPP = KRZYŻANOWSKI J. (red.) Nowa księga przystówi wyrażeń przystowiowych polskich . T. 1-4. Warszawa: Państowy Institut Wydawniczy, 1969-1978.

OUŘEDNíK 1994 = OUŘEDNíK P. Aniž jest co nového pod sluncem: slova, rčení a úsloví biblického původu. Praha: Mladá fronta, 1994.

PAVLASOVÁ 2013 = PAVLASOVÁ M. Rusko-české frazeologizmy biblckého původu s krestními jmény v komparativním aspektu. Bakalárská diplomová práce. Brno, 2013.

RADYSERB-WJELA 1902 = RADYSERB-WJELA J. Přistowa a přistowne hrónčka a wustowa Hornjotužiskich Serbow. Budyšin: Smolerjec serbskeje knihičiščernje, 1902.

SČFI 1983 = Slowník české frazeologie a idiomatiky. Přirovnání. Praha: Academia, 1983. SJPD = DoroszeWsKI W. (red.) Stownik języka polskiego. T. 1-11. Warszawa: PWN, 1997.

SKORUPKA = SKORUPKA S. Stownik frazeologiczny języka polskiego. T. 1-2. Warszawa: Wiedza Powszechna, 1967-1968.

SNK = Slovenský národný korpus. http://korpus.sk.

TREDER 1989 = TREDER J. Frazeologia kaszubska a wierzenia i zwyczaje (na tle porównawczym). Wejherowo: Muzeum Piśmiennictwa i Muzyki Kaszubsko-Pomorskiej, 1989.

VARŁYHA 1970 = VARŁYHA A. Krajovy stoŭnik Łahojščyny. New Jork: Vydańnie Zaranka, 1970.

WALTER 2008 = WALTER H. Wörterbuch deutscher sprichwörtlicher und phraseologischer Vergleiche. Teil 1. Hamburg: Dr. Kovač, 2008.

ZAORÁleK 2000 = ZAORÁLEK J. Lidová rčení. Praha: Academia, 2000. 